\title{
KAPITAŁ LUDZKI W ADMINISTRACJI SAMORZĄDOWEJ - PERSPEKTYWY ROZWOJU NA NAJBLIŻSZE DZIESIĘCIOLECIE
}

\section{Wstęp}

Dokonując oceny podległego nam pracownika, o każdym z nich można by powiedzieć, że jest mniej lub bardziej wartościowym. Oznacza to, że jest on w posiadaniu jakiegoś konkretnego potencjału, jakiejś mierzalnej wartości, która stanowi „kapitał ludzki”". Składa się na niego: wiedza, wykształcenie oraz umiejętności, lub też zdolności danego człowieka. Nie bez znaczenia jest także stan zdrowia, posiadana energia oraz motywacja do pracy. Kapitał ludzki w literaturze przedmiotu nie posiada jednolitej, spójnej definicji. Dla przykładu, zgodnie $\mathrm{z}$ podejściem badań ekonomicznych I. Fisher przedstawił koncepcję kapitału ludzkiego jako: „... źródło dochodu ucieleśnione $\mathrm{w}$ osobie pracownika ( $\mathrm{w}$ formie jego siły fizycznej oraz jego wrodzonych i nabytych umiejętności)"”. Halina Czubasiewicz oraz Bogdan Nogalski ${ }^{3}$ podają, że „kapitał ludzki należy do najcenniejszych zasobów każdej organizacji”.

\footnotetext{
*Doktorant, Wydział Zarządzania, Uniwersytet Gdański.

*** Doktorant, Wydział Zarządzania, Uniwersytet Gdański.

1 Kapitał ludzki, jako pojęcie ekonomiczne, oznacza zawarty w każdym człowieku i społeczeństwie jako całości zasób fachowej wiedzy, umiejętności, doświadczenia, zdrowia i energii życiowej. Kapitał ludzki jest wskaźnikiem możliwości adaptacyjnych i produkcyjnych oraz kreatywności. Nie jest wartością stałą, lecz można go zmieniać. Jego wartość można też podnieść poprzez inwestowanie w rozwój. Kapitał ludzki jest nieodłącznie i trwale połączony z człowiekiem, jest także częścią kapitału intelektualnego, który przypisywany jest organizacji.

B. Lev, A. Schwarz, On the Use of the Economic Concept of Human Capital in Financial Statements, „The Accounting Review”, Vol. 46, No 1, 1971, s. 103.

3 H. Czubasiewicz, B. Nogalski, Ocenianie motywacji pracowników i satysfakcji z pracy. Analiza przypadku, [w:] Pocztowski A. (red.), Praca izarządzanie kapitałem ludzkim $w$ perspektywie europejskiej, Oficyna Ekonomiczna, Kraków 2005, s. 504.
} 
Autorzy w niniejszej pracy pragną przybliżyć oraz przedstawić istotę kapitału ludzkiego w administracji samorządowej. Od czasu wprowadzenia samorządów w struktury administracji publicznej jesteśmy świadkami zmian, jakie dokonują się w tych organizacjach. Być może wielu przyzna, że tempo wprowadzania nowego podejścia do zarządzania $\mathrm{w}$ administracji publicznej budzi wiele zastrzeżeń. Jednakże zdaniem znawców tematu, podzielanym przez autorów pracy $\mathrm{z}$ uwagi na swe wieloletnie doświadczenie zawodowe, uznać należy, że wszelkie radykalne $\mathrm{i}$ nie do końca przemyślane zmiany są w administracji niewskazane. Bywa, że pod wpływem chwili lub też nacisków grup społecznych, wprowadzane są zmiany przepisów, które nim wejdą $\mathrm{w}$ życie, są równie pośpiesznie nowelizowane kolejną zmianą ustawy. Zmorą polskiego systemu prawnego jest jego niestabilność. Istnieje całe mnóstwo przepisów, które ulegają zmianie średnio co dwa miesiące. Nie sprzyja to prawidłowej i stabilnej pracy urzędu. Dodać należy, że urzędy, jako organizacje, także ulegają przemianom. Zmieniają się kultura organizacyjna (z władczej na służebną), systemy motywowania oraz sam sposób zarządzania urzędem i występującymi tam procesami. Dlatego tak ważne jest, aby na stanowiskach urzędniczych $\mathrm{w}$ administracji pracowali kompetentni i dobrze przygotowani do pracy $w$ takich warunkach pracownicy. Niniejsza praca ma za zadanie przedstawić w jakim kierunku zmierzają urzędy oraz jak rozwijać i szkolić pracowników samorządowych, aby sprostać czekającym ich wymaganiom.

\section{Zadania administracji samorządowej oraz rola pracownika samorządowego}

Termin administracja oznacza „zarządzanie, kierowanie, zawiadywanie, również zespół czymś zarządzający”4. Administracja publiczna działa w obrębie społeczności zorganizowanej w państwo, z jego instytucjami i istniejącym systemem unormowań prawnych. Jej prawne i ustrojowe funkcjonowanie wyznacza ustawa zasadnicza, jaką jest Konstytucja Rzeczpospolitej Polskiej z $1997 \mathrm{roku}^{5}$. Organy administracji w swoim zakresie mają następujące działania: wydają decyzje, nakazy, pozwolenia, zaświadczenia, zatrudniają pracowników

\footnotetext{
${ }^{4}$ Encyklopedia Powszechna, tom 1, Wydawnictwo MkRoom, Kraków 2009, s. 48.

5 Konstytucja Rzeczypospolitej Polskiej z dnia 2 kwietnia 1997 r., Dz. U. z 1997 r. Nr 78, poz. 483 z późn. zm.
} 
- zasoby ludzkie działające $\mathrm{w}$ administracji publicznej zawierają umowy, organizują przedsięwzięcia gospodarcze i społeczne.

Administrację publiczną w Polsce wykonują organy administracji publicznej i jednostki organizacyjne, które są aparatem wykonawczym tych organów. Administracja publiczna zorganizowana jest na szczeblu centralnym i terenowym.

Samorząd terytorialny ma długą tradycję. Jego początki nastąpiły po odzyskaniu niepodległości, trwał do wybuchu II wojny światowej $\mathrm{i}$ istniał na szczeblu gminy. Zlikwidowany został w 1950 roku i po długiej przerwie przywrócono go 8 marca 1990 roku ustawą o samorządzie gminnym.

Podstawową jednostką samorządu terytorialnego jest gmina. Poprzez gminę należy rozumieć prawnie zorganizowany związek osób, nazywany w ustawie jako „wspólnota samorządowa”, oraz odpowiednie terytorium - obszar kraju. Gmina posiada osobowość prawną, a o jej ustroju stanowi statut.

Celem utworzenia samorządów było realne oddanie w ręce wspólnot lokalnych zadań ich dotyczących. Założono, że relacje państwo - samorządy opierać się będą na zasadzie subsydiarności, która zakłada, że wszystkie decyzje powinny zapadać na szczeblu możliwie najbliższym obywatelom. Gmina wykonuje wszystkie zadania samorządu terytorialnego o znaczeniu lokalnym niezastrzeżone w ustawach dla innych jego jednostek. Za główne cele reformy samorządowej przyjęto:

- nowe ułożenie kompetencji administracji publicznej, uwzględniające jej zróżnicowanie funkcjonalne - interes lokalny, interes ogólny;

- uporządkowanie terytorialnej organizacji państwa przez zbudowanie jednolitej siatki terytorialnej i organizacyjnej dla całej administracji publicznej;

- przebudowa systemu finansów publicznych i wzrost efektywności zarządzania tymi funduszami;

- zwiększenie sterowalności państwa poprzez przeniesienie wielu zadań i kompetencji z centrum na niższe szczeble;

- budowa demokratycznego państwa;

- przystosowanie organizacji terytorialnej kraju i struktur do standardów Unii Europejskiej.

Reforma samorządowa z 1999 roku wprowadziła czytelny podział kompetencji między gminę i powiat, głównie $\mathrm{w}$ takich dziedzinach, jak oświata, służba zdrowia, pomoc społeczna.

Samorząd terytorialny jest organizacją publiczną, która tworząc warunki o charakterze regulacyjnym dla prowadzenia działalności 
gospodarczej wypełnia funkcje usługowe wobec lokalnej społeczności. Wpływa także na intensyfikację działalności gospodarczej poprzez instrumenty prawne, finansowe i organizacyjne. Każdy pracownik administracji samorządowej powinien interpretować prawo zgodnie z wartościami etycznymi, uniwersalnymi dla państwa demokratycznego. W ten sposób powiększa zakres swoich obowiązków, w myśl tych norm.

Zdaniem Barbary Kożuch ${ }^{6}$ to właśnie „organizacje samorządu terytorialnego, a zwłaszcza lokalnego, zajmują szczególnie ważne miejsce w sektorze publicznym, ponieważ ich główną funkcją jest działanie na rzecz zaspokajania potrzeb obywateli jako mieszkańców danego terytorium”. Dodaje, że ich „funkcjonowanie ma znaczny wpływ nie tylko na jakość oferowanych usług publicznych, ale również na tworzenie sprzyjającego (lub nie) klimatu"”.

Michał Kulesza ${ }^{8}$ w udzielonym wywiadzie przedstawia ciekawy punkt widzenia administracji oraz próbuje wytłumaczyć taki stan rzeczy. Podaje, że „w Polsce traktuje się administrację - zarówno tę rządową, jak i samorządową, jako zło konieczne, darmozjadów”. Tłumaczy, że jest to ,jakaś choroba”. Jego zdaniem jedynie sprawnie działająca administracja jest solidnym fundamentem każdego państwa, czy też gminy, gdyż to właśnie administracja ma olbrzymi wpływ zarówno na to, co dzieje się $\mathrm{w}$ sektorze publicznym, jak również $\mathrm{w}$ gospodarce $\mathrm{z}$ działającymi tam organizacjami prywatnymi. Samorząd, funkcjonując obecnie w świecie gospodarki rynkowej, z której pozyskuje inwestorów z pieniędzmi w celu realizacji zadań własnych, potrzebuje ludzi najlepszych, mogących sprostać tym niełatwym wymaganiom. Pokreślić tu należy, że „przez ostatnie 20 lat zadania administracji publicznej wzrosły, zwłaszcza po przystąpieniu Polski do Unii Europejskiej"9. Przy tak znacznym zwiększeniu zadań, uznać należy, że administracji nie jest tak wiele, jak się zwykło uważać. Za jej naturalny rozrost winić należy ustawodawcę, ponieważ to ustawodawca - wprowadzając nowe przepisy, obarcza ją wciąż nowymi zadaniami. Oczywistym jest więc, że - aby te zadania zrealizować, potrzeba ludzi.

\footnotetext{
${ }^{6}$ B. Kożuch, Zarzadzanie publiczne $w$ teorii i praktyce polskich organizacji, Wydawnictwo PLACET, Warszawa 2004, s.113.

${ }^{7}$ Tamże, s. 113 .

${ }^{8}$ M. Kulesza, Administracji nie jest w Polsce za dużo, „Kadra kierownicza w administracji”, Nr 13(14), styczeń 2012, s. 52.

${ }^{9}$ Ibidem, s. 52.
} 
Do realizacji zadań w zakresie administracji publicznej stworzono urzędy gmin, do których zakresu działania należy zapewnienie warunków należytego wykonywania spoczywających na gminie zadań własnych, zleconych oraz powierzonych.

Najważniejszą wartością organizacji jest czynnik ludzki. Bez dobrze dobranego personelu nie osiągnie się ambitnych celów, ani sukcesów. Pracownik administracji publicznej musi być dobrze wykształcony, wysoce wydajny, skuteczny w działaniu. Praca zawodowa jest podstawową sferą życia ludzkiego. Wymaga poświęcenia bardzo dużo czasu i energii. Może być źródłem motywacji, jeśli przynosi satysfakcję.

Motywowanie do pracy to jedna $\mathrm{z}$ najważniejszych funkcji zarządzania. Polega na wpływaniu na zachowania pracowników za pośrednictwem takich bodźców, które zostaną przez nich przekształcone $\mathrm{w}$ działanie zgodne $\mathrm{z}$ celami organizacji. Motywacja jest również rozumiana jako proces regulacji, pełniący funkcje sterowania czynnościami, w taki sposób, aby doprowadziły do osiągnięcia oczekiwanego wyniku. Motywacja jest siłą, która wywołuje, kierunkuje i podtrzymuje zachowania ludzi.

Można zadać sobie pytanie co tak naprawdę motywuje ludzi do działania, jak na ich motywację wpływają takie czynniki, jak inspirowanie, pobudzanie, zachęcanie, a nawet wymuszanie. Możemy pytać dalej co robić, aby pracownik w pełni wykorzystywał w pracy swoje uzdolnienia i energię twórczą. Należy szukać coraz doskonalszych form motywowania, biorąc pod uwagę predyspozycje pracownika oraz strukturę organizacji. Należy stworzyć takie motywatory, aby były akceptowane przez pracowników, a jednocześnie pobudzały ich do lepszej wydajności w pracy.

Administracja samorządowa, jako organizacja, różni się znacznie od innych funkcjonujących w gospodarce organizacji. Jej działania nie są nastawione na zysk, czy też na działania biznesowe. Głównym celem działania administracji samorządowej jest osiąganie dobrych wyników $w$ zakresie satysfakcji swoich klientów wewnętrznych i zewnętrznych oraz zaspokajanie ich potrzeb. Zgodnie z raportem Komisji Nolana, powołanej w 1994 roku, ustalono siedem zasad życia publicznego, do których należą ${ }^{10}$ :

- bezinteresowność,

- nieprzekupność,

- obiektywizm,

- odpowiedzialność,

${ }^{10}$ http://biurose.sejm.gov.pl/uzup/mid-202.pdf, dostęp na maj 2012. 
- jawność,

- uczciwość,

- przywództwo.

\section{Kierunki rozwoju jakości}

W całym sektorze publicznym podejmowane są w ostatnich latach działania skierowane na profesjonalizm oraz wzrost jakości. Aby tego dokonać, organizacja publiczna winna dysponować odpowiednio dobraną kadrą, która swoją pracę i obowiązki wykonywać będzie w oparciu o jasno określone zasady i standardy. Znaczny wpływ na powodzenie wprowadzanych zmian ma odpowiednie motywowanie pracowników. Halina Czubasiewicz ${ }^{11}$ podaje, że w większości organizacji podstawowym motywatorem do rozwoju pracowników jest system wynagradzania. Odpowiednio dobrany system motywowania oraz właściwa kultura organizacyjna zdaniem wielu naukowców są niezwykle ważne dla prawidłowego działania każdej organizacji, w tym także organizacji publicznej. A. P. Wiatrak $^{12}$ określił ,jakość" w ujęciu nauk o zarządzaniu jako odzwierciedlenie przyjętych kryteriów, norm i oczekiwań interesariuszy względem organizacji oraz wyrobów i usług przez nią oferowanych. Jednostki samorządu terytorialnego wdrażają obecnie różnorakie systemy, mające na celu poprawę jakości świadczonych usług. Jednym z pierwszych działań było przejście od administrowania do zarządzania, określane jako New Public Management (NPM). Nowe zarządzanie publiczne rozpowszechniło się w latach 80-tych ubiegłego wieku, głównie w krajach anglosaskich. Ch. Hood ${ }^{13}$ podaje, że koncepcja NPM zakłada wdrożenie siedmiu fundamentalnych doktryn:

- większy nacisk na kontrolę wyników świadczonych usług,

- profesjonalizacja zarządzania,

- wprowadzanie standardów i mierników działania,

- decentralizacja organizacji sektora publicznego,

${ }^{11}$ H. Czubasiewicz, Systemy wynagradzania a cechy kultury organizacyjnej, [w:] Juchnowicz M. (red), Kulturowe uwarunkowania zarzadzania kapitałem ludzkim, Oficyna Wolters Kluwer Polska, Warszawa 2009, s. 336.

${ }^{12}$ A. P. Wiatrak, Uwarunkowania jakości zarządzania w sektorze publicznym, „Prace i Materiały Wydziału Zarządzania Uniwersytetu Gdańskiego”, tom 4/1, Sopot 2011, s. 109.

13 Ch. Hood, A Public Management for All Seasons?, „Public Administration", vol. 69, 1991, s. 4-5. 
- wprowadzenie quasi-mechanizmów rynkowych,

- wykorzystanie narzędzi zarządzania stosowanych w sektorze biznesowym,

- nacisk na większe oszczędności wykorzystania zasobów.

W podejściu do zarządzania, opartym na zasadach NPM, ogromne znaczenie ma także orientacja i nastawienie na klienta. Przecież to on - „obywatel”, w codziennych kontaktach dokonuje na bieżąco oceny skuteczności działania urzędu. Aby poprawić jakość usług oraz efektywność działania organizacji publicznych, należy zidentyfikować procesy, a następnie podjąć próbę ich uporządkowania i optymalizacji. Wprowadzenie standaryzacji procesów udoskonali funkcjonowanie administracji samorządowej. Takie działania, nazywane przez naukę - Business Process Management - BPM, skutkują przejściem z zarządzania funkcjonalnego na procesowe. Pomocnym w tym zakresie może okazać się wprowadzenie systemów zarządzania jakością - normy ISO 9001 lub też ISO 14001. W Polsce już od 1998 roku w urzędach administracji publicznej zaczęto wprowadzać systemy zarządzania jakością w oparciu o standardy ISO serii 9000. Miało to na celu wzbudzenie zadowolenia klientów, poprzez zapoczątkowanie procesu podnoszenia jakości. Dalszym etapem jest wdrażanie modeli opartych na zasadach Kompleksowego Zarządzania przez Jakość (TQM). Ciekawy pogląd na dążenie do doskonałości organizacji przedstawił A. Hamrol w modelu EFQM (p. rysunek 1).

\section{Rysunek 1. Model doskonałości organizacji według EFQM Innowacje i uczenie się}

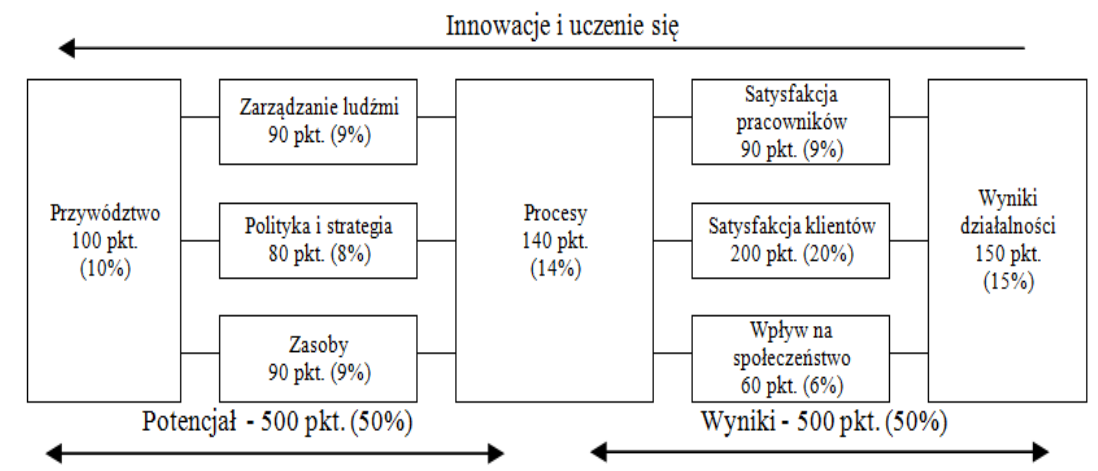

Źródło: A. Hamrol, Zarzadzanie jakościa z przykładami, Wydawnictwo Naukowe PWN, Warszawa 2008, s. 226. 
Przedstawiony model nie narzuca gotowych rozwiązań. Poruszając się w granicach ram, dostosowujemy model do możliwości oraz specyfiki danej organizacji. Model, po wdrożeniu, wykorzystywany jest do wsparcia oraz stymulacji działań, mających na celu usprawnienie funkcjonowania i jakości organizacji. Te wartości są ważne dla całej organizacji, bez względu na etap procesu. Od paru lat na znaczeniu zyskuje dostosowana do specyfiki organów administracji publicznej odmiana Modelu Doskonałości CAF - Powszechny Model Oceny. Dzięki współpracy ministerstw krajów Europy Zachodniej opublikowano w 2000 roku pilotażową wersję programu, która już po roku została wdrożona $\mathrm{w}$ wielu ministerstwach w Polsce. Zaproponowany model ma służyć jako narzędzie analityczne do dokonywania samooceny organizacji.

Dzięki staraniom takich organizacji, jak: Związek Miast Polskich, Związek Gmin Wiejskich RP oraz Związek Powiatów Polskich, od 2007 roku funkcjonuje i stale jest rozszerzana baza zawierająca opisy dobrych, sprawdzonych rozwiązań z zakresu usprawnienia funkcjonowania i jakości jednostek samorządu terytorialnego. Wszystkie te informacje znaleźć można na stronie internetowej www.dobrepraktyki.pl. Jest to namacalny dowód na zainteresowanie oraz dążenie administracji samorządowej do ciągłej poprawy, wskazanej w filozofii TQM.

Wskazane w artykule działania nakreślają kierunek rozwoju, jakim podąża administracja samorządowa. Sądząc po tempie zmian, stwierdzić należy, że w roku 2020 będziemy mieli do czynienia z zupełnie inną - Nową Administracją Samorządową.

\section{Ideał pracownika samorządowego}

Zasoby ludzkie $\mathrm{w}$ sektorze publicznym wywierają znaczący wpływ na jakość zarządzania. To od jakości tych zasobów zależna jest jakość świadczonych usług. $\mathrm{Na}$ podstawie przeprowadzonych obserwacji, jak i licznych badań, stwierdzić należy, że w administracji publicznej zauważalny jest brak odpowiedniej i wykwalifikowanej kadry. Szerzej na ten temat pisze A. Zalewski ${ }^{14}$, zwracając uwagę na upolitycznianie stanowisk $\mathrm{w}$ administracji oraz mającą $\mathrm{z}$ tym związek kadencyjność kadry i niektórych podległych osób. Na chwilę obecną,

14 A. Zalewski, Reformy sektora publicznego duchu nowego zarządzania publicznego, [w:] Zalewski A. (red.), Nowe zarzadzanie publiczne w polskim samorzadzie terytorialnym, Oficyna Wydawnicza SGH, Warszawa 2005, s. 39. 
oprócz niewystarczających środków na wykonywanie zadań publicznych, jest to największa przyczyna wpływająca na problemy z prawidłowym funkcjonowaniem administracji samorządowej.

W 2009 roku Ministerstwo Spaw Wewnętrznych i Administracji zleciło przeprowadzenie badań $\mathrm{w}$ ramach projektu „Zdiagnozowanie potencjału administracji samorządowej, ocena potrzeb szkoleniowych kadr urzędów administracji samorządowej oraz przygotowanie profili kompetencyjnych kadr urzędów administracji samorządowej”. W sferze dotyczącej podnoszenia jakości zasobów ludzkich urzędów jednostek samorządu terytorialnego, prowadzone badania wykazały, $\dot{\mathrm{z}} \mathrm{e}^{15}$ :

- urzędy administracji samorządowej wydają bardzo skromne środki na szkolenia pracownicze (średnio około $650 \mathrm{zł} \mathrm{w} \mathrm{przeliczeniu} \mathrm{na}$ 1 zatrudnionego, wyjątkiem są Urzędy Marszałkowskie, gdzie na szkolenia wydaje się niemal trzykrotnie więcej środków finansowych),

- tematycznego wyboru szkoleń dokonuje sie najczęściej w oparciu o identyfikowanie potrzeb urzędu w tym zakresie,

- ewaluacja szkoleń prowadzona jest w około połowie badanych urzędów (najczęściej stosowaną metodą pozostaje rozmowa przełożonego z podwładnym po ukończeniu szkolenia),

- potrzeby szkoleniowe $\mathrm{w}$ badanych urzędach koncentrują się głównie na kwestiach ekonomicznych (gospodarka lokalna, inwestycje, finanse i podatki, pozyskiwanie i rozliczanie środków unijnych), a rzadziej na kwestiach społecznych i obywatelskich oraz kultury i oświaty,

- w większości badanych urzędów fakt rozwijania kompetencji zawodowych przez pracownika poprzez jego uczestnictwo w szkoleniach nie podlega gratyfikowaniu ani w formie awansu w strukturach hierarchii urzędniczej, ani w formie awansu płacowego.

Zdaniem autorów raportu należy w sposób wydatny zwiększyć możliwości finansowe urzędów, pozwalające na inwestowanie w rozwój kompetencji pracowników poprzez szkolenia, z jednoczesnym doskonaleniem metod umożliwiających trafniejsze

15 B. Urbaniak, P. Bohdziewicz, Raport końcowy opracowany na zlecenie Ministerstwa Spraw Wewnętrznych i Administracji w ramach projektu pt. „Zdiagnozowanie potencjału administracji samorzadowej, ocena potrzeb szkoleniowych kadr urzędów administracji samorządowej oraz przygotowanie profili kompetencyjnych kadr urzędów administracji samorządowej”, Kutno 2009, s. 11-12. 
rozpoznawanie potrzeb szkoleniowych. Należy w sposób szczególny zwrócić uwagę na szkolenia pracownicze rozwijające umiejętności „miękkie”, prowadzone w formie warsztatowo - treningowej. Rozwój kompetencji własnych pracownika (wiedza, umiejętności profesjonalne) winien zawsze skutkować jedną $\mathrm{z}$ form awansu. Wartym wprowadzenia byłby także obowiązek podzielenia się zdobytą na szkoleniu wiedzą. Ta prosta metoda pozwoliłaby poszerzać wiedzę zawodową wśród współpracowników urzędu bez dodatkowych kosztów. Sporządzane profile kompetencji zawodowych powinny być wykorzystywane przede wszystkim, jako wyznacznik rozwoju zawodowego, który ściśle koreluje $\mathrm{z}$ awansem urzędniczym.

$\mathrm{Z}$ pomocą zastosowania zróżnicowanych technik badawczych, zestawiono opinie czterech badanych grup:

- pracowników administracji samorządowej (IDI),

- interesantów,

- osób przychodzących $\mathrm{w}$ różnych sprawach do urzędów samorządowych (CATI i Omnibus),

- niezależnych audytorów (Mystery Shopping).

Po zestawieniu wyników wszystkich czterech grup, można stworzyć model idealnego urzędnika (p. rysunek 2).

\section{Rysunek 2. Cechy idealnego urzędnika (N=1100; wg wskazań)}

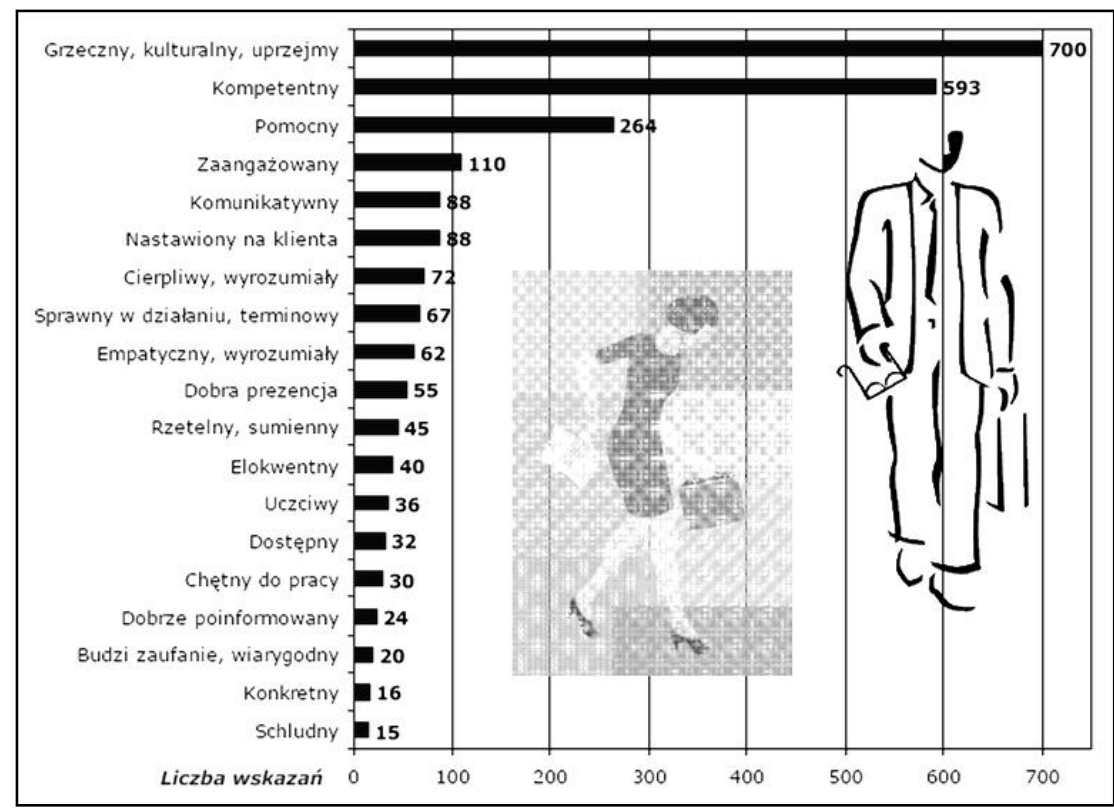

Źródło: B. Urbaniak, P. Bohdziewicz, Raport końcowy..., op. cit., s. 52. 
Wśród respondentów niewielki odsetek wyrażał skrajnie negatywne oceny. Cechy, jakich brakuje polskim urzędnikom, przedstawia rysunek 3. Obrazuje on jednocześnie kierunki rozwoju pracowników samorządowych.

\section{Rysunek 3. Cechy brakujące polskim urzędnikom ( $\mathrm{N}=500 ; \mathrm{w} \%)$}

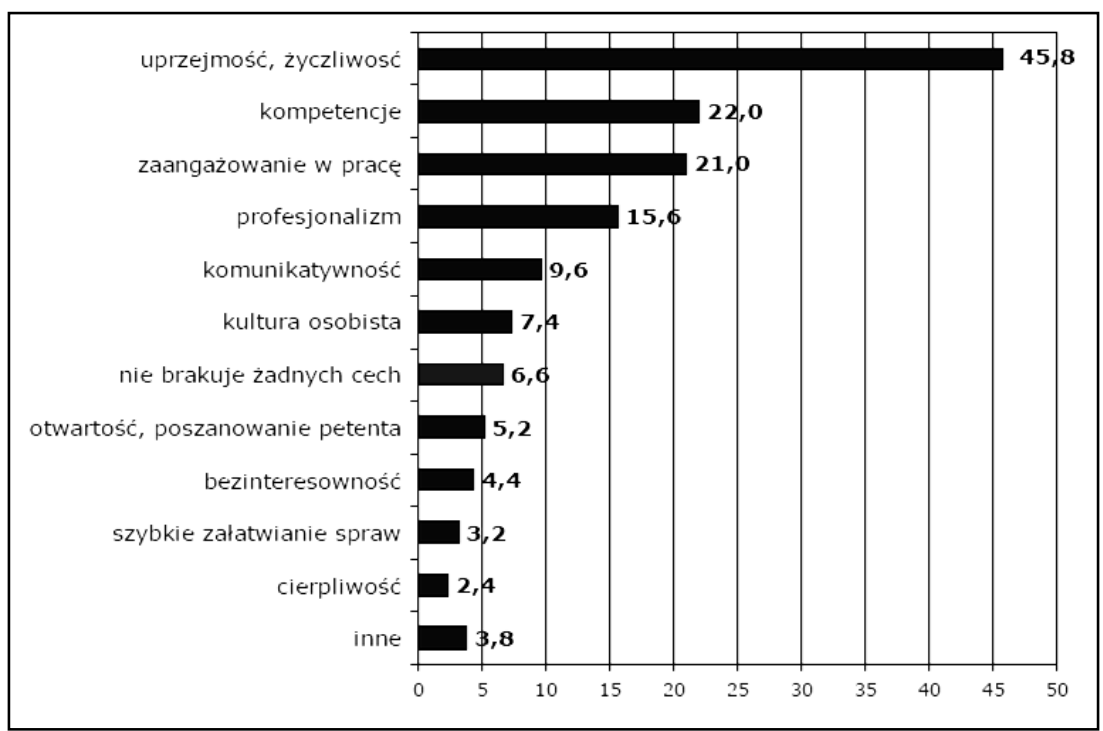

Źródło: B. Urbaniak, P. Bohdziewicz, Raport końcowy..., op.cit., s. 53.

Respondenci chwalą zwykle uprzejmość urzędników oraz prezencję (schludny ubiór). Wysoko oceniana jest też dyspozycyjność. Powyższe wyniki wskazują na zadowolenie i wysoki poziom satysfakcji z obsługi. Nie wyklucza to jednak działań poprawiających funkcjonowanie urzędu, ukierunkowanych na:

- zwiększenie uprzejmości i życzliwości urzędników,

- podniesienie kompetencji, wiedzy i wykształcenia urzędników,

- zwiększenie zaangażowania urzędników w wykonywanie zleconych zadań,

- poprawę komunikatywności urzędników i sposobu przekazywania odpowiednich informacji.

Reasumując powyższe wyniki badań, można stwierdzić, że „idealny urzędnik to taki, który dysponując swoją wiedzą w sposób uprzejmy i cierpliwy zaangażuje się w pomoc oraz udzieli właściwych 
informacji klientowi $\mathrm{w}$ celu sprawnego wykonania zleconych mu zadań" 16 .

\section{Podsumowanie}

Rozwój samorządu terytorialnego jest procesem ciągłym. Nie można więc mówić o jakimś modelu końcowym, który po ukończeniu ustabilizuje się na zawsze. Zmiany, jakie zachodzą w ustroju gminy we wszystkich państwach europejskich, mają charakter ewolucyjny. Wynikiem tych zmian jest współczesny demokratyczno samorządowy model gminy, który występuje w różnych wariantach ${ }^{17}$ :

- kliencko-patronacki - sprowadza się do obdarowywania społeczności lokalnej dobrami, będącymi w aktualnej dyspozycji środkami lub inwestycjami, w zamian za poparcie podczas wyborów oraz w czasie kluczowych etapów kadencji. Według informacji pojawiających się w literaturze przedmiotu wariant taki dominuje we Francji, Grecji, Hiszpanii, Turcji oraz we Włoszech;

- gmina państwa opiekuńczego - model ten zorientowany jest na kompleks zagadnień rozwoju lokalnego, jednak szczególną rolę przypisuje się w nim rozwojowi usług publicznych. Służyć ma maksymalizacji konsumpcji zbiorowej wspólnoty lokalnej. Dominuje w Danii, Holandii, Norwegii, Szwecji, a w łagodniejszym wymiarze - w Niemczech i Wielkiej Brytanii;

- ekonomiczno-rozwojowy - charakterystyczny jest dla USA, Kanady i Australii. Nadrzędnym celem władz lokalnych jest stymulowanie rozwoju gospodarczej sfery gminy oraz tych pozostałych sfer, które rozwojowi społecznemu służą.

$\mathrm{Na}$ całym świecie dąży się do usprawnienia działania administracji. Usprawnianie takie może być istotnym instrumentem ograniczającym, m.in. korupcję urzędniczą. Można przedstawić kilka najczęściej stosowanych kierunków zmian wprowadzanych na świecie ${ }^{18}$ :

- $\quad$ wprowadzanie systemu menadżerskiej administracji - wyłonionym w wyniku konkursu dyrektorom powierza się funkcje na podstawie umowy o dzieło;

\footnotetext{
${ }^{16}$ B. Urbaniak, P. Bohdziewicz, Raport końcowy..., op. cit., s. 60

17 T. G. Grosee, Nowe metody zarzadzania zadaniami publicznymi $w$ Unii Europejskiej i w Polsce, „Studia Polityczne”, Nr 17, 2005.

18 T. G. Grosse, M. Cabalski, Kodeks etyczny brytyjskiej służby cywilnej, Biuletyn Służby Cywilnej, nr 3, 1997.
} 
- wprowadzenie systemu motywacyjnego do pracy urzędników w postaci nagród oraz systemu awansowania na podstawie podnoszenia kwalifikacji zawodowych i na podstawie jakości wykonywanej pracy;

- wprowadzanie systemu „szybkiej ścieżki decyzyjnej” - dla spraw, za których przyspieszenie petent zgodził się ponieść dodatkową opłatę administracyjną. W ten sposób opłata, zamiast do kieszeni urzędnika, wpływa do budżetu danej jednostki;

- wprowadzenie większej liczby urzędników do obsługi najbardziej gorących obszarów usług administracyjnych - zmniejsza to przeciążenie urzędników pracą oraz pozwala petentom, w razie najmniejszych kłopotów natury korupcyjnej, skierować się do innego pracownika.

Wizerunek urzędów instytucji państwowych w dzisiejszych czasach w dużym stopniu buduje czynnik ludzki. Oczekiwania społeczeństwa wobec pracowników służb publicznych są bardzo konkretne i jednoznaczne. Każdy obywatel oczekuje, że zostanie dobrze i profesjonalnie obsłużony przez miłego, cierpliwego i kompetentnego urzędnika, tzn. z odpowiednimi umiejętnościami, kwalifikacjami, cechami psychofizycznymi i wiedzą.

Korzyści z zatrudniania osób o odpowiednich kompetencjach, dopasowanych do stanowiska pracy, są bardzo duże. Przede wszystkim taki pracownik ma odpowiednią motywację do pracy, bowiem zakres obowiązków nie jest ani za trudny, ani zbyt banalny. Pracownik wykonuje swoje obowiązki tak jak tego oczekuje pracodawca, wykorzystuje swój potencjał, swoje mocne strony, by efektywnie wykonywać zadania.

Współczesny pracownik administracji publicznej w swoim działaniu musi być wydajny i skuteczny. Aby to osiągnąć, pracodawca musi być zorientowany na potrzeby motywacyjne pracowników, a potrzeby te winny być przez cały czas monitorowane i udoskonalane. Właściwie i skuteczne monitorowanie zapewni pracownikom satysfakcję oraz zadowolenie $\mathrm{z}$ pracy. Usatysfakcjonowany i zadowolony pracownik, pewny stałości swojej pracy i wynagrodzenia, mający $\mathrm{w}$ perspektywie możliwości rozwoju i awansu, będzie wykonywał swoje obowiązki $\mathrm{z}$ największą starannością, $\mathrm{ku}$ zadowoleniu klienta zewnętrznego, współpracowników i przełożonych. 


\section{Bibliografia}

1. Konstytucja Rzeczypospolitej Polskiej z dnia 2 kwietnia 1997 r., Dz. U. z 1997 r. Nr 78, poz. 483 z późn. zm.

2. Czubasiewicz H., Nogalski B., Ocenianie motywacji pracowników i satysfakcji z pracy. Analiza przypadku, [w:] Pocztowski A. (red.), Praca $i$ zarzadzanie kapitatem ludzkim $w$ perspektywie europejskiej, Oficyna Ekonomiczna, Kraków 2005.

3. Czubasiewicz H., Systemy wynagradzania a cechy kultury organizacyjnej, [w:] Juchnowicz M. (red), Kulturowe uwarunkowania zarzadzania kapitałem ludzkim, Oficyna Wolters Kluwer Polska, Warszawa 2009.

4. Encyklopedia Powszechna, tom 1, Wydawnictwo MkRoom, Kraków 2009.

5. Grosse T.G., Nowe metody zarzadzania zadaniami publicznymi w Unii Europejskiej i w Polsce, „Studia Polityczne”, Nr 17, 2005.

6. Grosse T.G., Cabalski M., Kodeks etyczny brytyjskiej stużby cywilnej, Biuletyn Służby Cywilnej, Nr 3, 1997.

7. Hamrol A., Zarzadzanie jakościa z przyktadami, Wydawnictwo Naukowe PWN, Warszawa 2008.

8. Hood Ch., A Public Management for All Seasons?, „Public Administration", vol. 69, 1991.

9. Kożuch B., Zarzadzanie publiczne w teorii I praktyce polskich organizacji, Wydawnictwo PLACET, Warszawa 2004.

10. Kulesza M., Administracji nie jest $w$ Polsce za dużo, „Kadra kierownicza w administracji”, Nr 13(14), styczeń 2012.

11. Lev B., Schwarz A., On the Use of the Economic Concept of Human Capital in Financial Statements, „The Accounting Review", Vol. 46, No 1, 1971.

12. Urbaniak B., Bohdziewicz P., Raport końcowy opracowany na zlecenie Ministerstwa Spraw Wewnętrznych i Administracji, w ramach projektu pt. „Zdiagnozowanie potencjatu administracji samorzadowej, ocena potrzeb szkoleniowych kadr urzędów administracji samorzadowej oraz przygotowanie profili kompetencyjnych kadr urzędów administracji samorządowej", Kutno 2009.

13. Wiatrak A. P., Uwarunkowania jakości zarzadzania w sektorze publicznym, „Prace i Materiały Wydziału Zarządzania Uniwersytetu Gdańskiego", tom 4/1, Sopot 2011.

14. Zalewski A., Reformy sektora publicznego duchu nowego zarządzania publicznego, [w:] Zalewski A. (red.), Nowe zarządzanie publiczne $w$ polskim samorzadzie terytorialnym, 
Oficyna Wydawnicza SGH, Warszawa 2005.

\section{Strony internetowe}

1. http://biurose.sejm.gov.pl/uzup/mid-202.pdf.

2. www.dobrepraktyki.pl.

\section{Streszczenie}

$\mathrm{W}$ artykule przedstawiono istotę kapitału ludzkiego w administracji publicznej. Czynnik ludzki jest największą wartością organizacji. Pracownicy administracji publicznej muszą być dobrze wyedukowani, wysoce produktywni i efektywni w działaniu. Właściwe motywowanie pracowników ma bardzo ważny wpływ na kapitał ludzki.

Współcześnie jednostki administracji publicznej wprowadzają różne systemy w celu poprawy jakości świadczonych usług. Obserwując szybkie tempo zmian w tym zakresie, można przypuszczać, że do 2020 roku będziemy mieli do czynienia z zupełnie nową administracją publiczną.

\section{Summary}

\section{THE HUMAN CAPITAL IN LOCAL GOVERNMENT ADMINISTRATION - THE PROSPECTS OF DEVELOPMENT FOR THE NEXT DECADE}

In the article there was presented the essence of human capital in public administration. The most important value of the organization is human factor. The employees of public administration must be well educated, highly productive and effective in action. The proper motivating of employees exerts a significant influence on human capital.

Nowadays, the units of municipal administration are introducing different systems in order to improve the quality of services provided. Observing the rate of the changes, we can assume that in 2020 we will have to deal with a completely different New Public Administration. 